CESIS Electronic Working Paper Series

Paper No. 272

\title{
THE CREATIVE CLASS AND THE CRISIS
}

\author{
Todd Gabe \\ Richard Florida \\ Charlotta Mellander
}

April 2012 


\title{
THE CREATIVE CLASS AND THE CRISIS
}

\author{
Todd Gabe
}

\author{
Richard Florida
}

\section{Charlotta Mellander}

Gabe is professor of economics at the University of Maine, (todd.gabe@maine.edu). Florida is director of the Martin Prosperity Institute and professor of business and creativity at the Rotman School of Management, University of Toronto, (florida@rotman.utoronto.ca). Mellander is research director of the Prosperity Institute of Scandinavia, Jönköping International Business School, (charlotta.mellander@jibs.se).

\begin{abstract}
The economic crisis contributed to sharp increases in U.S. unemployment rates for all three of the major socio-economic classes. Results from regression models using individual-level data from the 2006-2011 U.S. Current Population Surveys indicate that members of the Creative Class had a lower probability of being unemployed over this period than individuals in the Service and Working Classes, and that the impact of having a creative occupation became more beneficial in the two years following the recession. These patterns, if they continue, are suggestive of a structural change occurring in the U.S. economy - one that favors knowledge-based creative activities.
\end{abstract}

Keywords: Economic Crisis, Great Recession, Creative Class, Service Class, Working Class, Unemployment

JEL: J6, J24, R0 


\section{INTRODUCTION}

The economic crisis of 2008 was deep and far reaching. Over a relatively short time period, the U.S. economy saw a reduction in the ranks of the employed of about 8.4 million individuals between January 2008 and December 2009, and the U.S. unemployment rate rose from 5.0 percent at the start of the economic slowdown in December 2007 to 9.5 percent at its official end in June 2009. ${ }^{1}$ But a broader measure of unemployment, the so-called U-6 unemployment rate-which also accounts for "marginally attached" workers and those who work part-time for "economic reasons"topped 17 percent in several months of 2009 and 2010.

Many observers of the U.S. and global economies have commented on the severity, defining characteristics and long-reaching implications of the recent economic downturn. Reinhart and Rogoff (2009) refer to it as the "Second Great Contraction," with the Great Depression being the first, and suggest that its impacts have been “extraordinary severe." After initiating the less somber description of a "Great Recession," Paul Krugman (2009) noted that it appeared that the United States was in a Second Great Depression. Scott Reynolds Nelson (2008) suggests that in many respects the current economic crisis bears more similarity to the even deeper Panic and Long Depression of the 1870s. Tyler Cowen (2011) dubs it a Great Stagnation, noting the diminishing pace of new discovery and the falling rate of productivity growth among advanced economies.

\footnotetext{
$1 \quad$ Seasonally-adjusted employment figures and unemployment rates are from the U.S. Bureau of Labor Statistics. The U.S. unemployment rate peaked at 10.1 percent in October of 2009. In June 2011, the U.S. unemployment rate was only slightly lower (9.2 percent) than where it stood two years earlier at the end of the recession ( 9.5 percent).
} 
Florida (2010) refers to the present economic era as a Great Reset, similar in scope and nature to the crises of the 1870s (the First Reset) and 1930s (the Second Reset), remarking that recovery will result in not only an accelerated rate of innovation and enhanced productivity but also new sources of consumer demand that stem from significant shifts in lifestyles and a new geography or spatial fix (Harvey 1981, 1982, 2003). Furthermore, Florida (2010) notes that the current crisis is more than a financial or economic crisis. He suggests that it is an even deeper structural divide as the productive and innovative capacities of the emergent knowledge-based creative economies came smack up against the outmoded institutions, economic and social structures and geographic forms of the old industrial age. This is suggestive of broader structural change in the economy - a shift in the nature and make up of employment.

Economists have noted that individuals without a college degree were hit particularly hard by the recession (Elsby, Hobijn and Sahin 2010; Katz 2010). The rate of unemployment for the college educated peaked at 5.0 percent in September 2009 while individuals 25 years and older without a college degree saw a high of 9.1 percent unemployment in September 2010. Autor (2010) suggests that the economic crisis "reinforced" the trend toward "skill-biased technical change" in the labor market - the combination of enhanced technology use (e.g., automation of routine tasks) and the globalization of labor markets, which has already contributed to a "polarization" of the labor market with employment opportunities concentrated in the highest and lowest skilled occupations, and a reduction of "middle-skill jobs." This perspective also suggests that the economic downturn has reinforced broader structural change in the economy, 
with the most substantial impacts hitting less skilled workers with lower levels of education (Autor 2010, Kolesnikova and Liu 2011). ${ }^{2}$

Although the receipt of a college degree is often used as a proxy for an individual's skill level, a person's occupation provides a strong indication of the types of skills that are actually used on the job. Florida's (2002) Creative Class—defined along occupational lines and including jobs such as engineers, artists, scientists and educatorsgrew rapidly from the smallest of the socio-economic classes (behind the Working and Service Classes) to the second largest major occupational group (behind only the Service Class) over the latter-half of the $20^{\text {th }}$ century. With the impacts of the 2008 recession on individuals with and without a college degree already known, the primary research question addressed in this paper is how members of the Creative Class fared during the Great Recession, as compared to those in the Service and Working Classes.

Numerous studies have examined the determinants of unemployment, although very little attention has been paid to differences across occupations or major occupational groups. ${ }^{3}$ Past studies, both those that report economy-wide unemployment statistics and others that involve regression analysis of state or metropolitan area unemployment rates, find that age, educational attainment, gender and race are key factors affecting unemployment (Mincer 1989; Fairlie and Sundstrom 1997; Azmat, Güell and Manning 2006; Daly, Jackson and Valletta 2007). A person's location of residence also appears to influence the likelihood of being unemployed, with a region's industrial structure (e.g.,

2 Groshen and Potter (2003) examine the role of structural change in the "jobless recovery" of 2001 to 2003 .

3 A notable exception is the recent study by Stolarick and Currid-Halkett (2011), which finds that a region's share of creative workers had a negative effect on U.S. metropolitan area unemployment rates during the economic crisis. This study examines regional unemployment rates during the recession, whereas the current paper uses micro-level data to examine the effect of Creative Class occupations on an individual's probability of being unemployed. 
diversification) explaining differences in unemployment rates across states and metropolitan areas (Simon 1988; Blanchard and Katz 1992; Malizia and Ke 1993; Partridge and Rickman 1997a, 1997b). Recent studies examining employment prospects during the Great Recession indicate that males, young workers, those without a college degree and ethnic minorities were hardest hit by the 2008 economic downturn (Elsby, Hobijn and Sahin 2010; Katz 2010). Our research accounts for the factors found in other studies to impact unemployment, but also investigates the impact of having a Creative Class occupation — a measure of human capital that is different than educational attainment—on an individual's probability of being unemployed in the years before, during and immediately following the Great Recession.

\section{WHY CREATIVE CLASS MEMBERS MIGHT HAVE FARED BETTER}

The Creative Class is comprised of the major occupational categories of computer and mathematical; architecture and engineering; life, physical, and social science; education, training, and library; arts, design, entertainment, sports, and media; management; business and financial operations; healthcare practitioners and technical; and high-end sales and sales management occupations. ${ }^{4}$

In contrast to the educational based human capital measure, the Creative Class occupational typology takes into account what people do in their current occupation, rather than their levels of education. The education based measure is fairly homogenous, differentiating only level of education, while the occupational measure identifies what workers actually do and the kinds of skills required for that work. This occupational based measure, it should also be noted, differs from the more conventional based measure

4 Creative, Service and Working Class definitions are from Florida (2002). 
of employment by "industry". The latter takes a variety of jobs in an industry - say for example both management and line workers employed in manufacturing, while an occupational focus separates out workers by what they actually do.

In times of crises, understanding the occupations of individuals provides particularly useful insights into the nature of work. For example, individuals in occupations with more standardized work may be easier to replace than individuals with more advanced, less routine oriented occupations. As a result, we therefore have good reasons to expect that in times of economic crises, working and service class jobs would be the first to be cut. Further, we could expect regions with higher shares of knowledge and creative workers to be more resilient in the face of economic downturns, and be better equipped to both reinvent themselves and also come up with new ideas and innovations that would drive the regional economy in times of recession. It is also likely that metros with higher levels of the creative class have employment structures and work forces as well as other institutions which give them higher levels of flexibility and resilience more generally. Thus these metros ability to better adjust to the economic crisis may also have across-the-board benefits to workers in service and working class jobs, mitigating the effects on these two classes of workers as well. Thus, the resilience and flexibility of metros with higher shares of creative class employment may also spillover to the other two classes of work.

Previous studies have also uncovered positive labor market and other economic outcomes associated with high creativity and the share of creative workers in a region (Knudsen et al. 2008; McGranahan, Wojan and Lambert 2011; Gabe 2011). Other occupational-based attributes that contribute to economic development benefits include 
cognitive, analytical, people and social intelligence skills (Bacolod, Blum and Strange 2009, Florida et al. 2011) and high knowledge related to information technology and business services (Gabe 2009; Abel and Gabe 2011).

There are several reasons why we might expect members of the Creative Class to have fared better during the recession than Working Class individuals and, to a lesser extent, those in Service Class occupations. First, one of the main causes of the economic slowdown was the mortgage crisis and steep downturn in housing activity (Mian and Sufi 2009a, 2009b, 2010). U.S. Bureau of Economic Analysis statistics from June 2011 indicate that "construction continued to be a drag on real GDP growth" and that it "declined for the sixth consecutive year and detracted from growth in most states." This reduction in building activity during the housing bust and continuing beyond the recession's official conclusion has adversely impacted employment conditions in construction occupations, which figure prominently in the Working Class. ${ }^{6}$

Another explanation as to why members of the Creative Class might have fared better than individuals in Service and Working Class occupations has to do with the nature of development that occurred alongside residential construction during the housing boom. In many places, housing growth during the early 2000s took place hand-in-hand with expanding retail and food service-related employment. This pattern of development, referred to as a "great growth illusion" (Florida 2010), is a false economy of sorts based on residential and commercial construction, expanding retail development and related service employment. Gabe and Florida (2011) found that regions characterized by high

5 These statements are from a June 7, 2011, U.S. Bureau of Economic Analysis news release, titled "Economic Recovery Widespread across States in 2010."

$6 \quad$ Kolesnikova and Liu (2011) note that construction industry employment decreased by 20 percent during the recession and that some of these job losses "are likely to be permanent." 
shares of employment in retail and food service occupations, along with specializations in construction, fared poorly during the recession. This means that, along with construction workers, individuals in retail and some service occupations - two large segments of the Service Class - might have been more adversely impacted by the recession than creative workers.

A third factor that might explain the differential impact of the recession on members of the Creative, Service and Working Classes is the economic slowdown's role in enhancing some longer-term structural changes in the U.S. economy (Autor 2010). Specifically, Autor, Levy and Murnane (2003) suggest that investments in computer technologies are "substitutes" for workers who perform tasks according to a set plan, while computers are "complements" to those involved in problem solving and complex communications. Florida (2002, p.71) characterizes occupations along similar lines: creative workers are problem solvers (and "problem finders"), while non-creative workers are more apt to follow instructions "dictated by a corporate template." These ideas suggest that members of the Creative Class-engineers, scientists, designers and the like-are more likely to be complements to technological change and, thus, were impacted less severely by the recession than non-creative workers.

Finally, as the economic crisis was a major worldwide slowdown in economic activity, jobs that rely heavily on export-driven growth were likely hit harder than occupations that are capable of generating locally-originating growth. ${ }^{7}$ The traditional export base model relates the economic growth of a region to its ability to produce a good, often manufactured or extracted, that can be sold to those outside the region (North

7 For example, Katz (2010) notes that workers in goods producing industries-important to Working Class Occupations-were disproportionately harmed by the recession 
1955). According to this theory, the reduction in global economic activity would have lowered the demand for workers in manufacturing or extractive-based occupationsprominently included in the Working Class - that rely heavily on exports. In contrast to the traditional export base model, Markusen's (2007) describes a consumption base theory of development in which, among other factors, investments in arts and culture can increase local spending and growth. Since this type of growth is not driven by a region's ability to export goods to other regions, the locally-induced growth spurred by artists and culture providers - key parts of the Creative Class—-might have led to less severe economic conditions for workers in these occupations.

\section{CONCEPTUAL FOUNDATION}

An individual's probability of being unemployed $(\mathrm{U})$ is related to his or her human capital and demographic characteristics, as well as industry- and region-specific factors, as shown in equation $1 .{ }^{8}$

$$
\begin{aligned}
& \operatorname{Pr}(\mathrm{U}=1)=\beta_{0}+\beta_{1} \text { Human Capital }+\beta_{2} \text { Demographic Characteristics }+ \\
& \beta_{3} \text { Industry Factors }+\beta_{4} \text { Regional Factors }+\varepsilon
\end{aligned}
$$

The human capital variables used in the empirical analysis include a set of dummy variables to indicate an individual's level of formal education (e.g., less than a high school degree, high school graduate / GED, associate degree, etc.) as well as variables to indicate a person's occupational class (e.g., Creative, Service or Working Class). Making a distinction between formal education and occupational class is important because, as noted by Florida, Mellander and Stolarick (2008, p.618), formal education provides a

This is the same general framework used by Azmat, Güell and Manning (2006) to examine the effect of gender on unemployment, while controlling for other demographic characteristics (e.g., age, education and marital status). 
measure of "potential talent or skill," whereas occupations provide an idea of how "human talent or capability is absorbed by and used by the economy."

Although there is some overlap between individuals with a college degree and those in Creative Class occupations, these measures of human capital do not always go hand-in-hand. Table 1 shows that whereas 63 percent of individuals in creative occupations have at least a four-year college degree - twice as high as the share of all workers (31 percent) - almost 20 percent of those in Service Class occupations and eight percent of the Working Class have this amount of formal education. Furthermore, as shown in the final two columns of Table 1, members of the Creative Class account for two-thirds of the U.S. workforce with at least a four-year college degree, while they represent 20 percent of the workforce without a college education. These figures suggest that one out of every three U.S. college-educated workers is in a non-creative occupation, while one out of every five U.S. workers without a college degree is a member of the Creative Class.

\section{(Table 1 about here)}

As discussed in the previous section, we would expect that working in a Creative Class occupation would have decreased an individual's probability of being unemployed during the Great Recession. The factors contributing to better employment prospects for creative workers include the recession's close ties to the mortgage / housing market crisis, which adversely impacted construction workers (members of the Working Class), as well as the connection between housing growth during the early 2000s and retail and 
food-service related employment, which—after the housing market downturn—might have lowered employment in some Service Class occupations. Two additional factors expected to lower the probability of being unemployed for members of the Creative Class include the recession's role in enhancing technology-induced structural changes in the U.S. economy (Autor 2010), and the idea that artistic and cultural (Creative Class) occupations are more closely tied to local consumption than export-oriented growth (Markusen 2007).

Along with the explanatory variables used to indicate an individual's occupational class and his or her level of formal education, the regression models also control for demographic characteristics such as age, gender, marital status, race and ethnicityfactors found in other studies to be associated with an individual's probability of being unemployed (Mincer 1989; Fairlie and Sundstrom 1997; Azmat, Güell and Manning 2006; Daly, Jackson and Valletta 2007; Elsby, Hobijn and Sahin 2010; Katz 2010). The role of industry factors in affecting a person's employment status is captured using a set of dummy variables to indicate an individual's major industrial (NAICS) category, and we account for region-specific factors by re-estimating the main regression model using data on individuals located in different types of metropolitan areas (by population size, share of the workforce in creative occupations, and regional unemployment rates).

\section{U.S. UNEMPLOYMENT RATES BETWEEN 2006 AND 2011}

The empirical analysis presented in the paper uses individual-level data from the 2006-2011 U.S. Current Population Surveys. This information is from March of each year, which means that the 2008-09 data are from time periods during the recession, the 
2006-07 data are from before the recession and the 2010-11 data are from after its official end date. ${ }^{9}$ All of the major occupational classes experienced increases in unemployment rates in the years "before" to "during" the recession, as well as the period of "during" to "after" the economic downturn (see Table 2). However, Creative Class occupations had an unemployment rate of 4.1 percent in the years following the recession's official end date, which - although higher than the 1.9 unemployment rate for similar occupations in 2006-07-was well below the overall unemployment rate of 4.7 percent prior to the beginning of the recession. In the two years following the recession, Working Class occupations had an unemployment rate of 14.6 percent—over three times greater than the unemployment rate for creative occupations - and Service Class occupations had an unemployment rate of 9.3 percent over that period.

\section{(Table 2 about here)}

Over all three periods, Creative Class occupations had substantially lower unemployment rates than Service and Working Class occupations. With a "before" to "after" increase in unemployment rates of 2.2 percentage points, creative occupations also had the smallest absolute change in unemployment over the period of 2006-07 to 2010-11. For Service Class occupations, the 5.0 percent unemployment rate in 2006-07 increased by 4.3 percentage points to a 9.3 percent unemployment rate in the years following the recession's official conclusion. On a percentage change basis, however, Service Class occupations had a lower increase in unemployment rates (86 percent) than

9 The unemployment rate in March 2007 was 4.4 percent, the lowest rate over the five years of 2003 to 2007 (although other months over this period also had unemployment rates of 4.4 percent). 
Creative Class occupations (116 percent) between 2006-07 and 2010-11. Of the three major occupational groups, Working Class occupations experienced the largest absolute (8.1 percentage points) and relative (125 percent) increases in unemployment rates.

\section{(Table 3 about here)}

Table 3 shows variations in U.S. unemployment rates over the period of 2006 to 2011 among the major occupational groups within the same educational cohort. As discussed earlier in the paper, the unemployment rate for those with at least a four-year college degree was lower-before, during and after the recession - than the unemployment rate for individuals without a college education. An analysis of differences among the occupational classes within the same educational cohort, however, reveals that members of the Creative Class always had a lower probability of being unemployed than individuals with similar amounts of education in the Service and Working Classes. Furthermore, members of the Creative Class without a college degree had a lower unemployment rate in all three periods than individuals with at least a fouryear college education in Service and Working Class occupations.

\section{(Table 4 about here)}

Just as the data show substantial differences in unemployment rates between 2006 and 2011 among the occupational classes, we also find considerable variation in employment prospects across major industrial categories. As shown in Table 4, the 
highest post-recession unemployment rates are found in the construction; management of companies and enterprises; arts, entertainment, and recreation; and accommodation and food services industries — in each case, above 12 percent over the 2010-11 time periodwhile post-recession unemployment rates were less than six percent in the educational services; utilities; healthcare and social assistance; and professional, scientific, and technical services industries. The largest "before" to "after" recession increases in unemployment rates were in the construction (11.3 percentage points), management of companies and enterprises (6.9 percentage points) and manufacturing (6.0 percentage points) sectors.

The unemployment rates shown in Tables 2, 3 and 4 are based on individuals located across the entire United States, which masks substantial disparities in labor market conditions across U.S. regions. As of June 2009, the U.S. metropolitan areas with the highest unemployment rates-e.g., El Centro, California (28.1 percent unemployment rate); Yuma, Arizona (22.6 percent); and Elkhart-Goshen, Indiana (19.4 percent)—had substantially worse job prospects than places such as Bismarck, North Dakota (3.7 percent unemployment rate); Iowa City, Iowa (4.0 percent); and Ames, Iowa (4.1 percent). Such a large spread in unemployment rates across U.S. metropolitan areas is likely attributed to, among other factors, differences in the extent to which they were exposed to the mortgage crisis and housing market boom turned to bust. Mian and Sufi (2009a, 2010) found that mortgage credit increased between 2002 and 2005 in places with high shares of subprime borrowers, and this growth was not supported by corresponding changes in incomes. The rapid expansion of household leverage over this period was a "powerful predictor" of the recession's impact on U.S. regions. 


\section{REGRESSION ANALYSIS}

Our empirical analysis examines an individual's probability of being unemployed between 2006 and 2011 through a probit regression analysis (see equation 1) of a dataset containing information on over 600,000 members of the U.S. workforce. The explanatory variables used in the regression models include measures of human capital—formal education and occupational class - and control for an individual's demographic characteristics (e.g., age, race, gender) and major industrial category. We account for the influence of regional factors by re-estimating the main regression model using data on individuals located in metropolitan areas that differ on the basis of population size, share of the workforce in creative occupations, and the unemployment rate near the end of the recession. Table 5 defines and reports summary statistics for the variables included in the analysis.

\section{(Table 5 about here)}

The dependent variable measures a person's employment status, with values of one and zero indicating being unemployed (6.5 percent of the sample) and having a job, respectively. Consistent with information from other sources (Florida 2002), we find the largest share of individuals reporting Service Class occupations (41.9 percent), followed by Creative Class (32.5 percent) and Working Class (22.2 percent) occupations. About 30 percent of the sample has at least a 4-year college degree-19.8 percent have a bachelor's degree and 10.5 percent have a graduate degree — and the typical individual in the data set 
is white ( 80.8 percent) and married (59.2 percent), with males representing a slightly higher share of the sample (52.1 percent) than females.

\section{(Table 6 about here)}

Table 6 presents marginal effects corresponding to probit regression results on the effects of an individual's major occupational class on his or her probability of being unemployed between 2006 and 2011. We estimate two regression models focusing on each of the major occupational classes, where the first model (columns 1, 3 and 5) examines the effect of the major occupational class on unemployment over the entire period and the second model (columns 2, 4 and 6) examines the extent to which the impact associated with an occupational class changed during and/or after the recession. The regression models are specified in a manner that isolates the effect of one of the occupational classes compared to the other two so that, for example, the marginal effect corresponding to the Creative Class indicator in the first column of results is interpreted as the effect on being unemployed associated with having a creative occupation as compared to a non-creative occupation.

Since the sample includes observations from three time periods_-before, during and after the recession - the regressions include dummy variables that indicate if the observation is from 2008-09 (during the recession) or 2010-11 (after the recession). A variable that measures the interaction between the During Recession indicator and membership in, for example, the Creative Class captures the extent to which the effect on 
being unemployed related to having a creative occupation differs in the years during the recession as compared to before its start.

Clearly, a person's occupational class significantly influences his or her probability of being unemployed. Marginal effects shown in the first column of results indicate that, other things being equal, belonging to the Creative Class lowers an individual's probability of not having a job by 2.2 percentage points over the period of 2006 to 2011. Estimates shown in the second column suggest that the negative effect on unemployment associated with having a Creative Class occupation was larger (i.e., more negative) in the years after the recession (2010-11) than before its official start. ${ }^{10}$ These results show that having a Creative Class occupation reduces an individual's probability of being unemployed by 1.9 percent points and that this effect decreased by 0.4 percentage points - to a total impact of 2.3 percentage points - after the recession.

Moving to the center two columns of results, we see that having a Service Class occupation does not have a significant effect on an individual's probability of being unemployed between 2006 and 2011, but that this occupational group's influence on unemployment changed over the period. Belonging to the Service Class increases an individual's probability of being unemployed by 0.7 percentage points, but this effect turned slightly negative in the years during the recession as well as after its official end date. As shown in the last two columns of Table 6, having a Working Class occupation is associated with a 2.5 percentage point increase in being unemployed over the period of 2006 to 2011 . This impact was significantly higher during and after the recession as

10 A Wald test of joint significance, conducted due to the inclusion of the interaction variables in the regression model, shows that having a Creative Class occupation (chi-squared $=778.35$; $\mathrm{p}$-value = 0.000 ) has a significant effect on an individual's probability of being unemployed. 
compared to the influence of having a Working Class occupation on unemployment in the years before the recession began.

The marginal effects reported in Table 6 also indicate that, along with his or her occupational class, an individual's level of formal education is associated with the probability of being unemployed. ${ }^{11}$ Looking at the first column of results, we see thatrelative to an omitted category of having a high school diploma / GED_-individuals without a high school education had a 2.1 percentage point higher probability of being unemployed, while those with an associate, bachelor's or graduate degree were $1.2,1.7$ and 2.1 percentage points less likely to be unemployed, respectively. The marginal effect associated with having a Creative Class occupation (-2.2 percentage points) is similar to the reduction in the probability of being unemployed related to having a graduate degree, but higher than the marginal effects associated with having an associate or bachelor's degree as a person's highest level of formal education.

Several of the demographic characteristics (e.g., age, race, marital status) used as control variables in the probit regression models have statistically significant marginal effects on an individual's probability of being unemployed. Although not shown in the table, the dummy variables indicating an individual's major industrial category are also important determinants of employment status. A Wald test of joint significance (p-value $=0.000$ ) shows that, as a group, the industry controls have a significant effect on an individual's probability of being unemployed.

The final three tables of results show the marginal effects associated with having a Creative Class occupation on the probability of being unemployed in different types of

11 A Wald test of joint significance shows that educational attainment (chi-squared $=3,165 ; \mathrm{p}$-value $=0.000$ ) has a significant effect on an individual's probability of being unemployed. 
U.S. metropolitan areas. Tables 7, 8 and 9 summarize the results from regressions using data on individuals located in metropolitan areas that differ by population size, share of the workforce in creative occupations, and unemployment, respectively. This approach, which groups individuals into sub-samples based on the similarity of his or her metropolitan area, allows us to "strip away" the influence of these regional factors on unemployment, but it also illustrates how the effect of having a Creative Class occupation on unemployment differs across regions.

\section{(Table 7 about here)}

For all three of the regional variables, we grouped the metropolitan areas into ten categories based on their decile rankings. ${ }^{12}$ As shown in Table 7 , the groups of metropolitan areas varied considerably in terms of average population size, from 127,030 to about 5.0 million people. These groups, categorized based on population size, also differed somewhat in terms of average unemployment rates and the share of the workforce in creative occupations. The marginal effects associated with having a Creative Class occupation on the probability of being unemployed are remarkably similar for the very smallest (deciles 1 and 2) and the moderate- to larger-sized metropolitan areas (deciles 5 to 10 )_ ranging from -0.018 to -0.019 . The influence of having a Creative Class occupation on unemployment, however, is slightly more pronounced (i.e., a larger negative impact) in the third and fourth population size deciles, which have average populations of around 200,000 to 250,000 people.

12 The analysis is based on 570,476 individuals located in 257 U.S. metropolitan areas. 
(Table 8 about here)

The descriptive information shown in Table 8 suggests - consistent with the findings reported by Stolarick and Currid-Halkett (2011) — that metropolitan areas with the lowest shares of creative workers tended to have higher average unemployment rates than places with a greater percentage of the workforce in the Creative Class. The impact of having a creative occupation on the likelihood of being unemployed, however, tends to be slightly stronger (i.e., larger negative values) — with the exception of the third decilein metropolitan areas with lower shares of creative workers. The marginal effects associated with Creative Class occupations range from -0.016 to -0.019 in the top four deciles in terms of a metropolitan area's creative class share, but they are -0.021 or below (i.e., larger negative values) in 5 of the 6 bottom deciles.

\section{(Table 9 about here)}

Finally, the results shown in Table 9 suggest that the impacts of having a creative occupation on employment status are slightly more beneficial (i.e., larger reduction in the probability of being unemployed) in metropolitan areas with the highest unemployment rates (deciles 9 and 10) than in places with more favorable employment prospects. The marginal effects associated with Creative Class occupations range from -0.015 to -0.020 in the bottom eight deciles in terms of a metropolitan area's unemployment rate, but they are -0.025 and -0.022 in the ninth and tenth deciles, respectively. Although a complete analysis of the differences in the effects of Creative Class occupations on the probability 
of being unemployment across metropolitan areas is beyond the scope of this paper, the marginal effects summarized in Table 7,8 and 9 suggest that belonging to the Creative Class lowers an individual's probability of not having a job in all types of U.S. regions.

\section{SUMMARY AND CONCLUSIONS}

Our research has examined an individual's probability of being unemployed over the period of 2006 to 2011, with a particular emphasis on the influence of his or her major occupational class. The paper examined the effects of major occupational groupi.e., membership in the Creative, Service and Working Classes-on an individual's employment status in the years before, during and after the Great Recession of 2008. Descriptive analysis of individual-level data from the 2006 to 2011 Current Population Surveys shows that Creative Class occupations had relatively low unemployment rates compared to the overall U.S. economy prior to the official start of the recession (1.9 percent versus 4.7 percent), during the economic slowdown (3.0 percent versus 6.9 percent), and in the years immediately following the recession (4.1 percent versus 9.4 percent). In all three periods, the major group of Creative Class occupations had substantially lower rates of unemployment than Service and Working Class occupations. For example, Working Class occupations had an unemployment rate of 14.6 percent in 2010-12, after the recession ended, up from the 6.5 percent unemployment rate for these occupations in 2006-07 before the Great Recession's official onset.

Findings from our probit regression analysis further indicate that — controlling for educational attainment, several demographic characteristics and major industrial 
category - an individual's occupational class has a significant effect on his or her likelihood of being unemployed. Specifically, we find that, other things being equal, having a Creative Class occupation lowered an individual's probability of being unemployed by 2.2 percentage points between 2006 and 2011, while having a Working Class occupation increased the likelihood of not having a job. Additionally, we find that the impact on the probability of being unemployed associated with having a Creative Class occupation decreased in the two years following the recession. Conversely, the impact on an individual's employment status associated with having a Working Class occupation became more detrimental during and after the recession. Having a Service Class occupation does not have a significant effect on an individual's probability of being unemployed over the entire period of 2006 to 2011, but that this occupational group's influence on unemployment changed - i.e., larger reduction in unemployment rate-in the years during and after the recession. Our main results related to the impact of Creative Class occupations on the probability of being unemployed are robust to re-estimating the regression models using samples of the population in metropolitan areas that differ on the basis of population size, share of the workforce in creative occupations, and unemployment rate.

The empirical evidence presented in the paper suggests that having a Creative Class occupation lowers an individual's probability of being unemployed — in fact, the effect is larger than the marginal effect associated with having a four-year college degree (compared to someone with only a high school diploma) — and that the impact of having a creative occupation became more beneficial in the two years following the recession. These results, along with our findings related to the other major occupational groups, are 
indicative of a structural change taking place in the U.S. economy. This shift is characterized by high — and growing — unemployment in Working Class occupations, whereas the relative position of creative workers improved in the years following the recession. Although we cannot pinpoint a specific factor (or group of factors) that have caused such a shift, our results are consistent with a reduction in Working Class employment opportunities associated with the housing market crash (Kolesnikova and Liu 2011) as well as the Great Recession's role in enhancing longer-term, technologyinduced structural changes occurring in the U.S. economy (Autor 2010). If these trends continue, they will contribute to the sort of Great Reset described by Florida (2010) as an economic transformation that favors knowledge-based creative activities. 


\section{REFERENCES}

Abel, Jaison R. and Todd Gabe. 2011. "Human Capital and Economic Activity in Urban America," Regional Studies, 45, 1079-1090.

Autor, David. 2010. "The Polarization of Job Opportunities in the U.S. Labor Market: Implications for Employment and Earnings,” The Hamilton Project, April 2010.

Autor, David, Frank Levy, and Richard Murnane. 2003. "The Skill Content of Recent Technological Change: An Empirical Exploration," Quarterly Journal of Economics, 118, 1279-1333.

Azmat, Ghazala, Maia Güell and Alan Manning. 2006. "Gender Gaps in Unemployment Rates in OECD Countries," Journal of Labor Economics, 24, 1-37.

Bacolod, Marigee, Bernardo Blum, and William Strange. 2009. "Skills and the City," Journal of Urban Economics, 65, 136-153

Blanchard, Olivier and Lawrence Katz. 1992. "Regional Evolutions," Brookings Papers on Economic Activity, 1992, 1-75.

Card, David. 1999. "The Causal Effects of Education on Earnings," in an Orley Ashenfelter and David Card (eds), Handbook of Labor Economics. Amsterdam: Elsevier, pp. 1801-1863.

Cowen, Tyler. 2011. The Great Stagnation, New York: Dutton (Penguin Group).

Daly, Mary, Osborne Jackson and Robert Valletta. 2007. "Educational Attainment, Unemployment, and Wage Inflation,” Federal Reserve Bank of San Francisco 2007 Economic Review, pp. 49-61. 
Elsby, Michael, Bart Hobijn and Aysegul Sahin. 2010. "The Labor Market in the Great Recession,” Brookings Papers on Economic Activity, Spring 2010.

Fairlie, Robert and William Sundstrom. 1997. "The Racial Unemployment Gap in LongRun Perspective," American Economic Review, 87, 306-310.

Florida, Richard. 2002. The Rise of the Creative Class, New York: Basic Books.

Florida, Richard. 2010. The Great Reset, New York: HarperCollins Publishers.

Florida, Richard, Charlotta Mellander and Kevin Stolarick. 2008. "Inside the Black Box of Regional Development-Human Capital, the Creative Class and Tolerance," Journal of Economic Geography, 8, 615-649.

Florida, Richard, Charlotta Mellander, Kevin Stolarick and Adrienne Ross. 2011. "Cities, Skills and Wages," Journal of Economic Geography, forthcoming.

Gabe, Todd. 2009. "Knowledge and Earnings," Journal of Regional Science, 49, 439457.

Gabe, Todd. 2011. "The Value of Creativity," in a David Andersson, Ake Andersson and Charlotta Mellander (eds), Handbook of Creative Cities. Cheltenham, UK: Edward Elgar, pp. 128-145.

Gabe, Todd and Richard Florida. 2011. "Effects of the Housing Boom and Bust on U.S. Metro Employment," unpublished manuscript.

Groshen, Erica and Simon Potter. 2003. "Has Structural Change Contributed to a Jobless Recovery?" Current Issues in Economics and Finance, August 2003, Federal Reserve Bank of New York.

Harvey, David. 1981. "The Spatial Fix: Hegel, Von Thünen and Marx,” Antipode, 13, 112. 
Harvey, David. 1982. The Limits of Capital, New York: Oxford University Press.

Harvey, David. 2003. The New Imperialism, New York: Oxford University Press.

Katz, Lawrence. 2010. "Long-Term Unemployment in the Great Recession,” Testimony for the Joint Economic Committee, U.S. Congress, April 29, 2010.

King, Miriam, Steven Ruggles, J. Trent Alexander, Sarah Flood, Katie Genadek, Matthew B. Schroeder, Brandon Trampe, and Rebecca Vick. Integrated Public Use Microdata Series, Current Population Survey: Version 3.0. [Machinereadable database]. Minneapolis: University of Minnesota, 2010.

Knudsen, Brian, Richard Florida, Kevin Stolarick and Gary Gates. 2008. "Density and Creativity in U.S. Regions," Annals of the Association of American Geographers, $98,461-478$.

Kolesnikova, Natalia and Yang Liu. 2011. "Jobless Recoveries: Causes and Consequences," The Regional Economist, April 2011, Federal Reserve Bank of St. Louis.

Krugman, Paul. 2009. "Fighting Off Depression", New York Times, 2009/04/01, Available at: http://www.nytimes.com/2009/01/05/opinion/05krugman.html.

Markusen, Ann. "A Consumption Base Theory of Development: An Application to the Rural Cultural Economy," Agricultural and Resource Economics Review, 36, 923.

Malizia, Emil and Shanzi Ke. 1993. "The Influence of Economic Diversity of Unemployment and Stability," Journal of Regional Science, 33, 221-235. 
McGranahan, David, Timothy Wojan and Dayton Lambert. 2011. "The Rural Growth Trifecta: Outdoor Amenities, Creative Class and Entrepreneurial Context," Journal of Economic Geography, 11, 529-557.

Mian, Atif and Amir Sufi. 2009a. "The Consequences of Mortgage Credit Expansion: Evidence from the U.S. Mortgage Default Crisis," Quarterly Journal of Economics, 124, 1449-1496.

Mian, Atif and Amir Sufi. 2009b. "Household Leverage and the Recession of 2007 to 2009," Paper presented at the 10th Jacques Polak Annual Research Conference, International Monetary Fund, Washington, DC.

Mian, Atif and Amir Sufi. 2010. "The Great Recession: Lessons from Microeconomic Data," American Economic Review, 100, 1-10.

Mincer, Jacob. 1989. "Human Capital and the Labor Market: A Review of Current Research," Educational Researcher, 18, 27-34.

Nelson, Scott. 2008. "The Real Great Depression," The Chronicle of Higher Education: The Chronicle Review, 55(8): B98

North, Douglass. 1955. "Location Theory and Regional Economic Growth," Journal of Political Economy, 63, 243-258.

Partridge, Mark and Dan Rickman. 1997a. "The Dispersion of US State Unemployment Rates: The Role of Market and Non-market Equilibrium Factors," Regional Studies, 31, 593-606.

Partridge, Mark and Dan Rickman. 1997b. "State Unemployment Differentials: Equilibrium Factors vs. Differential Employment Growth," Growth and Change, 28, 360-379. 
Reinhart, Carmen and Kenneth Rogoff. 2009. This Time is Different. Princeton, NJ: Princeton University Press.

Simon, Curtis. 1988. "Frictional Unemployment and the Role of Industrial Diversity," Quarterly Journal of Economics, 103,715-728.

Stolarick, Kevin and Elizabeth Currid-Halkett. 2011. "Creativity and the Crisis: The Impact of Creative Workers on Regional Unemployment," unpublished manuscript. 
Table 1. College Attainment Rates by Occupational Class

\begin{tabular}{lcccc} 
Occupations & $\begin{array}{c}\text { \% in Occupational } \\
\text { Class w/ Degree }\end{array}$ & $\begin{array}{c}\text { \% of Workforce } \\
\text { by Occupational Class }\end{array}$ & $\begin{array}{c}\text { w/ College Degree By } \\
\text { Occupational Class }\end{array}$ & $\begin{array}{c}\text { Workforce w/out } \\
\text { College Degree by } \\
\text { Occupational Class }\end{array}$ \\
\hline All Occupations & $31.1 \%$ & NA & NA & NA \\
Creative Class & $62.7 \%$ & $35.6 \%$ & $66.1 \%$ & $20.0 \%$ \\
Service Class & $19.8 \%$ & $38.2 \%$ & $22.4 \%$ & $46.2 \%$ \\
Working Class & $7.5 \%$ & $22.7 \%$ & $5.0 \%$ & $31.7 \%$ \\
\end{tabular}

Information used to calculate the figures shown in the table is from the 2006-2011 U.S. Current Population Surveys (March), accessed through IPUMS-CPS (King et al. 2010). Values in the final three columns do not sum to $100 \%$ because the sample excludes farming, fishing, and forestry occupations - which are not included in Florida's Creative, Service or Working Classes. 
Table 2. U.S. Unemployment Rates by Occupational Class

\begin{tabular}{|c|c|c|c|c|c|c|}
\hline Occupations & $\begin{array}{c}\text { Before } \\
\text { Recession } \\
\end{array}$ & $\begin{array}{c}\text { During } \\
\text { Recession } \\
\end{array}$ & $\begin{array}{c}\text { Change } \\
\text { Before to During }\end{array}$ & $\begin{array}{c}\text { After } \\
\text { Recession } \\
\end{array}$ & $\begin{array}{c}\text { Change } \\
\text { During to After }\end{array}$ & $\begin{array}{c}\text { Change } \\
\text { Before to After }\end{array}$ \\
\hline All Occupations & 4.7 & 6.9 & 2.2 & 9.4 & 2.5 & 4.7 \\
\hline Creative Class & 1.9 & 3.0 & 1.1 & 4.1 & 1.1 & 2.2 \\
\hline Service Class & 5.0 & 6.9 & 1.9 & 9.3 & 2.4 & 4.3 \\
\hline Working Class & 6.5 & 11.1 & 4.6 & 14.6 & 3.5 & 8.1 \\
\hline
\end{tabular}

Information used to calculate unemployment rates is from the U.S. Current Population Survey (March), accessed through IPUMS-CPS (King et al. 2010). "Before recession" unemployment rates are based on data from 2006 and 2007, "during recession" rates are based on data from 2008 and 2009, and "after recession" rates are based on data from 2010 and 2011. The official dates of the 2008 recession were from December 2007 to June 2009. 
Table 3. U.S. Unemployment Rates by College Attainment Status

\begin{tabular}{|c|c|c|c|c|c|c|}
\hline Industry & $\begin{array}{c}\text { Before } \\
\text { Recession } \\
\end{array}$ & $\begin{array}{c}\text { During } \\
\text { Recession } \\
\end{array}$ & $\begin{array}{c}\text { Change } \\
\text { Before to During }\end{array}$ & $\begin{array}{c}\text { After } \\
\text { Recession } \\
\end{array}$ & $\begin{array}{c}\text { Change } \\
\text { During to After }\end{array}$ & $\begin{array}{c}\text { Change } \\
\text { Before to After }\end{array}$ \\
\hline College Degree & 1.9 & 3.1 & 1.2 & 4.2 & 1.1 & 2.3 \\
\hline Creative Class & 1.5 & 2.4 & 0.9 & 3.2 & 0.8 & 1.7 \\
\hline Service Class & 2.7 & 4.0 & 1.3 & 5.9 & 1.9 & 3.2 \\
\hline Working Class & 4.1 & 7.1 & 3.0 & 8.7 & 1.6 & 4.6 \\
\hline No College Degree & 5.9 & 8.6 & 2.7 & 11.7 & 3.1 & 5.8 \\
\hline Creative Class & 2.4 & 3.9 & 1.5 & 5.7 & 1.8 & 3.3 \\
\hline Service Class & 5.4 & 7.4 & 2.0 & 10.0 & 2.6 & 4.6 \\
\hline Working Class & 6.6 & 11.4 & 4.8 & 15.1 & 3.7 & 8.5 \\
\hline
\end{tabular}

Information used to calculate unemployment rates is from the U.S. Current Population Survey (March), accessed through IPUMS-CPS (King et al. 2010). "Before recession" unemployment rates are based on data from 2006 and 2007, "during recession" rates are based on data from 2008 and 2009, and "after recession" rates are based on data from 2010 and 2011. The official dates of the 2008 recession were from December 2007 to June 2009. 
Table 4. U.S. Unemployment Rates by Major Industrial Category

\begin{tabular}{|c|c|c|c|c|c|c|}
\hline Industry & $\begin{array}{c}\text { Before } \\
\text { Recession } \\
\end{array}$ & $\begin{array}{c}\text { During } \\
\text { Recession } \\
\end{array}$ & $\begin{array}{c}\text { Change } \\
\text { Before to During }\end{array}$ & $\begin{array}{c}\text { After } \\
\text { Recession } \\
\end{array}$ & $\begin{array}{c}\text { Change } \\
\text { During to After }\end{array}$ & $\begin{array}{c}\text { Change } \\
\text { Before to After }\end{array}$ \\
\hline All Industries & 4.7 & 6.9 & 2.2 & 9.4 & 2.5 & 4.7 \\
\hline $\begin{array}{l}\text { Forestry, fishing, hunting, } \\
\text { and Agriculture Support }\end{array}$ & 5.8 & 7.7 & 1.9 & 10.4 & 2.7 & 4.6 \\
\hline $\begin{array}{l}\text { Mining, quarrying, and oil } \\
\text { and gas extraction }\end{array}$ & 2.9 & 7.5 & 4.6 & 7.5 & 0.0 & 4.6 \\
\hline Utilities & 2.0 & 3.6 & 1.6 & 4.3 & 0.7 & 2.3 \\
\hline Construction & 7.9 & 14.2 & 6.3 & 19.2 & 5.0 & 11.3 \\
\hline Manufacturing & 4.3 & 8.1 & 3.8 & 10.3 & 2.2 & 6.0 \\
\hline Wholesale trade & 3.5 & 5.1 & 1.6 & 7.4 & 2.3 & 3.9 \\
\hline Retail trade & 5.0 & 7.3 & 2.3 & 9.5 & 2.2 & 4.5 \\
\hline $\begin{array}{l}\text { Transportation and } \\
\text { warehousing }\end{array}$ & 4.0 & 6.4 & 2.4 & 9.0 & 2.6 & 5.0 \\
\hline Information & 3.5 & 5.9 & 2.4 & 8.0 & 2.1 & 4.5 \\
\hline Finance and insurance & 2.5 & 4 & 1.5 & 6.6 & 2.6 & 4.1 \\
\hline $\begin{array}{l}\text { Real estate and rental and } \\
\text { leasing }\end{array}$ & 3.4 & 5.7 & 2.3 & 7.6 & 1.9 & 4.2 \\
\hline $\begin{array}{l}\text { Professional, scientific, and } \\
\text { technical services }\end{array}$ & 2.7 & 4.4 & 1.7 & 5.6 & 1.2 & 2.9 \\
\hline $\begin{array}{l}\text { Management of companies } \\
\text { and enterprises }\end{array}$ & 9.3 & 13.3 & 4.0 & 16.2 & 2.9 & 6.9 \\
\hline
\end{tabular}

\footnotetext{
Table is continued on the following page.
} 
Table 4. U.S. Unemployment Rates by Major Industrial Category, continued

\begin{tabular}{|c|c|c|c|c|c|c|}
\hline Industry & $\begin{array}{c}\text { Before } \\
\text { Recession } \\
\end{array}$ & $\begin{array}{c}\text { During } \\
\text { Recession } \\
\end{array}$ & $\begin{array}{c}\text { Change } \\
\text { Before to During }\end{array}$ & $\begin{array}{c}\text { After } \\
\text { Recession } \\
\end{array}$ & $\begin{array}{c}\text { Change } \\
\text { During to After } \\
\end{array}$ & $\begin{array}{c}\text { Change } \\
\text { Before to After } \\
\end{array}$ \\
\hline $\begin{array}{l}\text { Administrative and Support } \\
\text { and Waste Management and } \\
\text { Remediation Services }\end{array}$ & 6.7 & 7.1 & 0.4 & 10.6 & 3.5 & 3.9 \\
\hline Educational services & 1.8 & 2.3 & 0.5 & 3.2 & 0.9 & 1.4 \\
\hline $\begin{array}{l}\text { Health care and social } \\
\text { assistance }\end{array}$ & 2.6 & 3.5 & 0.9 & 5.2 & 1.7 & 2.6 \\
\hline $\begin{array}{l}\text { Arts, entertainment, and } \\
\text { recreation }\end{array}$ & 7.2 & 8.1 & 0.9 & 12.7 & 4.6 & 5.5 \\
\hline $\begin{array}{l}\text { Accommodation and food } \\
\text { services }\end{array}$ & 7.2 & 9.4 & 2.2 & 12.4 & 3.0 & 5.2 \\
\hline $\begin{array}{l}\text { Other services (except } \\
\text { public administration) }\end{array}$ & 3.6 & 4.7 & 1.1 & 7 & 2.3 & 3.4 \\
\hline
\end{tabular}

Information used to calculate unemployment rates is from the U.S. Current Population Survey (March), accessed through IPUMS-CPS (King et al. 2010). "Before recession" unemployment rates are based on data from 2006 and 2007, "during recession" rates are based on data from 2008 and 2009, and "after recession" rates are based on data from 2010 and 2011. The official dates of the 2008 recession were from December 2007 to June 2009. 
Table 5. Variable Definitions and Summary Statistics $(n=610,513)$

\begin{tabular}{|c|c|c|c|}
\hline Variable Name & Variable Definition & Mean & $\begin{array}{l}\text { Standard } \\
\text { Deviation } \\
\end{array}$ \\
\hline Unemployed & $\begin{array}{l}=1 \text { if person is in labor force and } \\
\text { unemployed; }=0 \text { if person is in labor } \\
\text { force and employed }\end{array}$ & 0.065 & NA \\
\hline Creative Class & $\begin{array}{l}=1 \text { if person reports an occupation of } \\
\text { computer and mathematical; } \\
\text { architecture and engineering; life, } \\
\text { physical, and social science; } \\
\text { education, training, and library; arts, } \\
\text { design, entertainment, sports, and } \\
\text { media; management; business and } \\
\text { financial operations; legal; or } \\
\text { healthcare practitioners and } \\
\text { technical; =0 otherwise }\end{array}$ & 0.325 & NA \\
\hline Service Class & $\begin{array}{l}=1 \text { if person reports an occupation of } \\
\text { health care support; food preparation } \\
\text { and food-service related; building } \\
\text { and grounds cleaning and } \\
\text { maintenance; personal care and } \\
\text { service; sales and related; office and } \\
\text { administrative support; community } \\
\text { and social services; or protective } \\
\text { services; =0 otherwise }\end{array}$ & 0.419 & NA \\
\hline Working Class & $\begin{array}{l}=1 \text { if person reports an occupation of } \\
\text { construction and extraction; } \\
\text { installation, maintenance, and repair; } \\
\text { production; or transportation and } \\
\text { material moving; =0 otherwise }\end{array}$ & 0.222 & NA \\
\hline Age & Person's age (in years) & 40.9 & 13.4 \\
\hline No High School & $\begin{array}{l}=1 \text { if person is not a high school } \\
\text { graduate / GED; }=0 \text { otherwise }\end{array}$ & 0.121 & NA \\
\hline
\end{tabular}

Table is continued on the following page. 
Table 5. Variable Definitions and Summary Statistics, continued $(\mathrm{n}=610,513)$

\begin{tabular}{|c|c|c|c|}
\hline Variable Name & Variable Definition & Mean & $\begin{array}{l}\text { Standard } \\
\text { Deviation }\end{array}$ \\
\hline High School & $\begin{array}{l}=1 \text { if person's highest level of } \\
\text { education is a high school graduate / } \\
\text { GED; }=0 \text { otherwise }\end{array}$ & 0.478 & NA \\
\hline Associate Degree & $\begin{array}{l}=1 \text { if person's highest level of } \\
\text { education is an associate Degree; }=0 \\
\text { otherwise }\end{array}$ & 0.098 & NA \\
\hline Bachelor's Degree & $\begin{array}{l}=1 \text { if person's highest level of } \\
\text { education is a bachelor's Degree; }=0 \\
\text { otherwise }\end{array}$ & 0.198 & NA \\
\hline Graduate Degree & $\begin{array}{l}=1 \text { if person's highest level of } \\
\text { education is a graduate or } \\
\text { professional degree; }=0 \text { otherwise }\end{array}$ & 0.105 & NA \\
\hline Hispanic & $\begin{array}{l}=1 \text { if person is Hispanic; }=0 \\
\text { otherwise }\end{array}$ & 0.157 & NA \\
\hline White & $=1$ if person is white $;=0$ otherwise & 0.808 & NA \\
\hline Black & $=1$ if person is black; $=0$ otherwise & 0.106 & NA \\
\hline Asian & $=1$ if person is Asian; $=0$ otherwise & 0.051 & NA \\
\hline Other Race & $\begin{array}{l}=1 \text { if person indicated a race other } \\
\text { than white, black or Asian; }=0 \\
\text { otherwise }\end{array}$ & 0.036 & NA \\
\hline Male & $=1$ if person is male; $=0$ otherwise & 0.521 & NA \\
\hline Married & $=1$ if person is married; $=0$ otherwise & 0.592 & NA \\
\hline Before Recession & $\begin{array}{l}=1 \text { if observation is from } 2006 \text { or } \\
2007 ;=0 \text { otherwise }\end{array}$ & 0.336 & NA \\
\hline During Recession & $\begin{array}{l}=1 \text { if observation is from } 2008 \text { or } \\
2009 ;=0 \text { otherwise }\end{array}$ & 0.336 & NA \\
\hline
\end{tabular}

Table is continued on the following page. 
Table 5. Variable Definitions and Summary Statistics, continued $(n=610,513)$

\begin{tabular}{lllc}
\hline Variable Name & Variable Definition & Mean & $\begin{array}{c}\text { Standard } \\
\text { Deviation }\end{array}$ \\
\hline After Recession & $\begin{array}{l}=1 \text { if observation is from 2010 or } \\
2011 ;=0 \text { otherwise }\end{array}$ & 0.327 & NA \\
& & & \\
\hline
\end{tabular}

Notes: The sample is limited to labor force participants. All variables are from the U.S. Current Population Survey (2006 to 2011), accessed through IPUMS-CPS (King et al., 2010). Creative, Service and Working Class definitions are from Florida (2002). 
Table 6. Probit Regression Results: Effects of Occupational Class on Unemployment

\begin{tabular}{|c|c|c|c|c|c|c|}
\hline \multirow{2}{*}{$\begin{array}{l}\text { Variable } \\
\text { Constant }\end{array}$} & \multicolumn{6}{|c|}{ Marginal effects (standard errors in parentheses) } \\
\hline & $\begin{array}{l}-0.128 * \\
(0.003)\end{array}$ & $\begin{array}{l}-0.129 * \\
(0.003)\end{array}$ & $\begin{array}{l}-0.129 * \\
(0.003)\end{array}$ & $\begin{array}{l}-0.133^{*} \\
(0.003)\end{array}$ & $\begin{array}{l}-0.139 * \\
(0.003)\end{array}$ & $\begin{array}{l}-0.136 * \\
(0.003)\end{array}$ \\
\hline Creative Class & $\begin{array}{l}-0.022 * \\
(0.001)\end{array}$ & $\begin{array}{l}-0.019 * \\
(0.001)\end{array}$ & NA & NA & NA & NA \\
\hline $\begin{array}{l}\text { Creative Class } x \\
\text { After Recession }\end{array}$ & NA & $\begin{array}{l}-0.004 * \\
(0.002)\end{array}$ & NA & NA & NA & NA \\
\hline Service Class & NA & NA & $\begin{array}{c}-6.77 \mathrm{E}-05 \\
(0.001)\end{array}$ & $\begin{array}{l}0.007 * \\
(0.001)\end{array}$ & NA & NA \\
\hline $\begin{array}{l}\text { Service Class } x \\
\text { After Recession }\end{array}$ & NA & NA & NA & $\begin{array}{l}-0.008 * \\
(0.001)\end{array}$ & NA & NA \\
\hline Working Class & NA & NA & NA & NA & $\begin{array}{l}0.025^{*} \\
(0.001)\end{array}$ & $\begin{array}{l}0.012 * \\
(0.001)\end{array}$ \\
\hline
\end{tabular}

Table is continued on the following page. 
Table 6. Probit Regression Results: Effects of Occupational Class on Unemployment, continued

\begin{tabular}{|c|c|c|c|c|c|c|}
\hline \multirow{2}{*}{$\begin{array}{l}\text { Variable } \\
\\
\text { Working Class } x \\
\text { During Recession }\end{array}$} & \multicolumn{6}{|c|}{ Marginal effects (standard errors in parentheses) } \\
\hline & NA & NA & NA & NA & NA & $\begin{array}{l}0.017 * \\
(0.002)\end{array}$ \\
\hline $\begin{array}{l}\text { Working Class } x \\
\text { After Recession }\end{array}$ & NA & NA & NA & NA & NA & $\begin{array}{l}0.018 * \\
(0.002)\end{array}$ \\
\hline Age & $\begin{array}{l}-0.001 * \\
(0.0001)\end{array}$ & $\begin{array}{l}-0.001 * \\
(0.0001)\end{array}$ & $\begin{array}{l}-0.001 * \\
(0.0001)\end{array}$ & $\begin{array}{l}-0.001 * \\
(0.0001)\end{array}$ & $\begin{array}{l}-0.001 * \\
(0.0001)\end{array}$ & $\begin{array}{l}-0.001 * \\
(0.0001)\end{array}$ \\
\hline$A g e^{\wedge} 2$ & $\begin{array}{l}6.31 \mathrm{E}-06^{*} \\
(1.35 \mathrm{E}-06)\end{array}$ & $\begin{array}{l}6.36 \mathrm{E}-06^{*} \\
(1.35 \mathrm{E}-06)\end{array}$ & $\begin{array}{l}7.38 \mathrm{E}-06^{*} \\
(1.36 \mathrm{E}-06)\end{array}$ & $\begin{array}{l}7.29 \mathrm{E}-06^{*} \\
(1.36 \mathrm{E}-06)\end{array}$ & $\begin{array}{l}8.80 \mathrm{E}-06^{*} \\
(1.35 \mathrm{E}-06)\end{array}$ & $\begin{array}{l}8.83 \mathrm{E}-06^{*} \\
(1.35 \mathrm{E}-06)\end{array}$ \\
\hline No High School & $\begin{array}{l}0.021 * \\
(0.001)\end{array}$ & $\begin{array}{l}0.021 * \\
(0.001)\end{array}$ & $\begin{array}{l}0.022 * \\
(0.001)\end{array}$ & $\begin{array}{l}0.022 * \\
(0.001)\end{array}$ & $\begin{array}{l}0.021 * \\
(0.001)\end{array}$ & $\begin{array}{l}0.021 * \\
(0.001)\end{array}$ \\
\hline Associate Degree & $\begin{array}{c}-0.012 * \\
(0.001)\end{array}$ & $\begin{array}{c}-0.012 * \\
(0.001)\end{array}$ & $\begin{array}{c}-0.014 * \\
(0.001)\end{array}$ & $\begin{array}{c}-0.014 * \\
(0.001)\end{array}$ & $\begin{array}{c}-0.013 * \\
(0.001)\end{array}$ & $\begin{array}{c}-0.013 * \\
(0.001)\end{array}$ \\
\hline Bachelor's Degree & $\begin{array}{c}-0.017 * \\
(0.001)\end{array}$ & $\begin{array}{c}-0.017 * \\
(0.001)\end{array}$ & $\begin{array}{c}-0.022 * \\
(0.001)\end{array}$ & $\begin{array}{l}-0.022 * \\
(0.001)\end{array}$ & $\begin{array}{c}-0.019 * \\
(0.001)\end{array}$ & $\begin{array}{c}-0.019 * \\
(0.001)\end{array}$ \\
\hline Graduate Degree & $\begin{array}{l}-0.021 * \\
(0.001)\end{array}$ & $\begin{array}{l}-0.021 * \\
(0.001)\end{array}$ & $\begin{array}{l}-0.028 * \\
(0.001)\end{array}$ & $\begin{array}{l}-0.028 * \\
(0.001)\end{array}$ & $\begin{array}{l}-0.025^{*} \\
(0.001)\end{array}$ & $\begin{array}{l}-0.025 * \\
(0.001)\end{array}$ \\
\hline
\end{tabular}

Table is continued on the following page. 
Table 6. Probit Regression Results: Effects of Occupational Class on Unemployment, continued

\begin{tabular}{|c|c|c|c|c|c|c|}
\hline \multirow{2}{*}{$\begin{array}{l}\text { Variable } \\
\text { Hispanic }\end{array}$} & \multicolumn{6}{|c|}{ Marginal effects (standard errors in parentheses) } \\
\hline & $\begin{array}{c}0.001 \\
(0.001)\end{array}$ & $\begin{array}{c}0.001 \\
(0.001)\end{array}$ & $\begin{array}{l}0.002 * \\
(0.001)\end{array}$ & $\begin{array}{l}0.002 * \\
(0.001)\end{array}$ & $\begin{array}{r}0.002 * * \\
(0.001)\end{array}$ & $\begin{array}{c}0.002 * * \\
(0.001)\end{array}$ \\
\hline Black & $\begin{array}{c}0.036^{*} \\
(0.001)\end{array}$ & $\begin{array}{l}0.036 * \\
(0.001)\end{array}$ & $\begin{array}{l}0.038^{*} \\
(0.001)\end{array}$ & $\begin{array}{l}0.038^{*} \\
(0.001)\end{array}$ & $\begin{array}{l}0.037 * \\
(0.001)\end{array}$ & $\begin{array}{l}0.037 * \\
(0.001)\end{array}$ \\
\hline Asian & $\begin{array}{c}-0.002 * * * \\
(0.001)\end{array}$ & $\begin{array}{c}-0.002 * * * \\
(0.001)\end{array}$ & $\begin{array}{c}-0.002 \\
(0.001)\end{array}$ & $\begin{array}{c}-0.002 \\
(0.001)\end{array}$ & $\begin{array}{c}-0.002 \\
(0.001)\end{array}$ & $\begin{array}{c}-0.002 \\
(0.001)\end{array}$ \\
\hline Other Race & $\begin{array}{l}0.025 * \\
(0.002)\end{array}$ & $\begin{array}{l}0.025 * \\
(0.002)\end{array}$ & $\begin{array}{l}0.026 * \\
(0.002)\end{array}$ & $\begin{array}{l}0.026 * \\
(0.002)\end{array}$ & $\begin{array}{l}0.025 * \\
(0.002)\end{array}$ & $\begin{array}{l}0.025 * \\
(0.002)\end{array}$ \\
\hline Male & $\begin{array}{c}0.001 \\
(0.001)\end{array}$ & $\begin{array}{c}0.001 \\
(0.001)\end{array}$ & $\begin{array}{c}0.001 \\
(0.001)\end{array}$ & $\begin{array}{c}0.001 \\
(0.001)\end{array}$ & $\begin{array}{c}-0.003 * \\
(0.001)\end{array}$ & $\begin{array}{c}-0.003 * \\
(0.001)\end{array}$ \\
\hline Married & $\begin{array}{c}-0.029 * \\
(0.001)\end{array}$ & $\begin{array}{c}-0.029 * \\
(0.001)\end{array}$ & $\begin{array}{c}-0.030 * \\
(0.001)\end{array}$ & $\begin{array}{c}-0.030 * \\
(0.001)\end{array}$ & $\begin{array}{c}-0.029 * \\
(0.001)\end{array}$ & $\begin{array}{c}-0.029 * \\
(0.001)\end{array}$ \\
\hline During Recession & $\begin{array}{c}0.025^{*} \\
(0.001)\end{array}$ & $\begin{array}{c}0.025^{*} \\
(0.001)\end{array}$ & $\begin{array}{c}0.025^{*} \\
(0.001)\end{array}$ & $\begin{array}{l}0.030^{*} \\
(0.001)\end{array}$ & $\begin{array}{l}0.025^{*} \\
(0.001)\end{array}$ & $\begin{array}{l}0.020^{*} \\
(0.001)\end{array}$ \\
\hline
\end{tabular}

Table is continued on the following page. 
Table 6. Probit Regression Results: Effects of Occupational Class on Unemployment, continued

\begin{tabular}{|c|c|c|c|c|c|c|}
\hline \multirow{2}{*}{$\begin{array}{l}\text { Variable } \\
\text { After Recession }\end{array}$} & \multicolumn{6}{|c|}{ Marginal effects (standard errors in parentheses) } \\
\hline & $\begin{array}{l}0.047 * \\
(0.001)\end{array}$ & $\begin{array}{l}0.048^{*} \\
(0.001)\end{array}$ & $\begin{array}{l}0.047^{*} \\
(0.001)\end{array}$ & $\begin{array}{l}0.052^{*} \\
(0.001)\end{array}$ & $\begin{array}{l}0.047 * \\
(0.001)\end{array}$ & $\begin{array}{l}0.041^{*} \\
(0.001)\end{array}$ \\
\hline $\begin{array}{l}\text { Chi-squared } \\
\text { p-value }\end{array}$ & $\begin{array}{l}24,982 \\
0.0000\end{array}$ & $\begin{array}{l}24,989 \\
0.0000\end{array}$ & $\begin{array}{l}24,124 \\
0.0000\end{array}$ & $\begin{array}{l}24,179 \\
0.0000\end{array}$ & $\begin{array}{l}24,860 \\
0.0000\end{array}$ & $\begin{array}{l}24,992 \\
0.0000\end{array}$ \\
\hline Sample Size & 610,531 & 610,513 & 610,513 & 610,513 & 610,513 & 610,513 \\
\hline
\end{tabular}

Notes: The superscripts $*, * *$ and $* * *$ denote statistical significance at the 1-, 5- and 10-percent levels. The regression models also include dummy variables, not shown in the table, that control for an individual's major industrial category. 
Table 7. Summary Probit Regression Results: Effects of Creative Class Occupations on Unemployment across the Metropolitan Area Population Size Hierarchy

\begin{tabular}{|c|c|c|c|c|}
\hline $\begin{array}{l}\text { Population } \\
\text { Size Decile }\end{array}$ & $\begin{array}{c}\text { Average } \\
\text { Population }\end{array}$ & Unemployed & $\begin{array}{l}\% \text { Workforce } \\
\text { Creative Class }\end{array}$ & $\begin{array}{l}\text { Marginal Effect } \\
\text { of Creative Class }\end{array}$ \\
\hline 1 & 127,030 & 0.067 & 0.275 & $\begin{array}{l}-0.019^{*} \\
(0.005)\end{array}$ \\
\hline 2 & 163,625 & 0.059 & 0.310 & $\begin{array}{l}-0.018^{*} \\
(0.004)\end{array}$ \\
\hline 3 & 208,865 & 0.052 & 0.313 & $\begin{array}{l}-0.025^{*} \\
(0.003)\end{array}$ \\
\hline 4 & 260,664 & 0.066 & 0.289 & $\begin{array}{l}-0.023 * \\
(0.004)\end{array}$ \\
\hline 5 & 335,653 & 0.058 & 0.324 & $\begin{array}{l}-0.019 * \\
(0.004)\end{array}$ \\
\hline 6 & 422,593 & 0.069 & 0.303 & $\begin{array}{l}-0.019 * \\
(0.004)\end{array}$ \\
\hline 7 & 564,167 & 0.057 & 0.329 & $\begin{array}{l}-0.018^{*} \\
(0.002)\end{array}$ \\
\hline 8 & 791,383 & 0.055 & 0.327 & $\begin{array}{l}-0.018^{*} \\
(0.002)\end{array}$ \\
\hline 9 & $1,487,974$ & 0.061 & 0.329 & $\begin{array}{l}-0.018 * \\
(0.002)\end{array}$ \\
\hline 10 & $4,986,888$ & 0.062 & 0.356 & $\begin{array}{c}-0.018^{*} \\
(0.001)\end{array}$ \\
\hline
\end{tabular}

Notes: Standard errors are shown in parentheses. The superscript $*$ denotes statistical significance at the 1-percent level. Marginal effects are from probit regression models that include the explanatory variables shown in Table 6, as well as dummy variables that control for an individual's major industrial category. Population figures used to determine decile rankings are from the U.S. Census Bureau, 2009 American Community Survey. 
Table 8. Summary Probit Regression Results: Effects of Creative Class Occupations on Unemployment across Metropolitan Areas with Different Shares of Creative Workers

\begin{tabular}{|c|c|c|c|}
\hline $\begin{array}{c}\text { Creative Class Workforce } \\
\text { Share Decile }\end{array}$ & Unemployed & $\begin{array}{l}\% \text { Workforce } \\
\text { Creative Class } \\
\end{array}$ & $\begin{array}{l}\text { Marginal Effect } \\
\text { of Creative Class }\end{array}$ \\
\hline 1 & 0.068 & 0.247 & $\begin{array}{l}-0.021 * \\
(0.004)\end{array}$ \\
\hline 2 & 0.067 & 0.261 & $\begin{array}{l}-0.024 * \\
(0.005)\end{array}$ \\
\hline 3 & 0.075 & 0.270 & $\begin{array}{l}-0.017 * \\
(0.004)\end{array}$ \\
\hline 4 & 0.061 & 0.294 & $\begin{array}{l}-0.025 * \\
(0.003)\end{array}$ \\
\hline 5 & 0.060 & 0.303 & $\begin{array}{l}-0.021 * \\
(0.003)\end{array}$ \\
\hline 6 & 0.058 & 0.317 & $\begin{array}{l}-0.021 * \\
(0.003)\end{array}$ \\
\hline 7 & 0.060 & 0.327 & $\begin{array}{l}-0.019 * \\
(0.002)\end{array}$ \\
\hline 8 & 0.061 & 0.333 & $\begin{array}{l}-0.017 * \\
(0.002)\end{array}$ \\
\hline 9 & 0.061 & 0.342 & $\begin{array}{l}-0.016 * \\
(0.001)\end{array}$ \\
\hline 10 & 0.056 & 0.415 & $\begin{array}{c}-0.019 * \\
(0.002)\end{array}$ \\
\hline
\end{tabular}

Notes: Standard errors are shown in parentheses. The superscript $*$ denotes statistical significance at the 1-percent level. Marginal effects are from probit regression models that include the explanatory variables shown in Table 6, as well as dummy variables that control for an individual's major industrial category. Creative Class workforce figures used to determine decile rankings are from the U.S. Bureau of Labor Statistics, 2009 Occupational Employment Statistics. 
Table 9. Summary Probit Regression Results: Effects of Creative Class Occupations on Unemployment across Metropolitan Areas with Different Unemployment Rates

\begin{tabular}{|c|c|c|c|}
\hline $\begin{array}{l}\text { Unemployment } \\
\text { Rate Decile }\end{array}$ & Unemployed & $\begin{array}{l}\% \text { Workforce } \\
\text { Creative Class }\end{array}$ & $\begin{array}{l}\text { Marginal Effect } \\
\text { of Creative Class }\end{array}$ \\
\hline 1 & 0.044 & 0.377 & $\begin{array}{l}-0.015 * \\
(0.002)\end{array}$ \\
\hline 2 & 0.049 & 0.336 & $\begin{array}{l}-0.018 * \\
(0.002)\end{array}$ \\
\hline 3 & 0.057 & 0.356 & $\begin{array}{l}-0.017 * \\
(0.002)\end{array}$ \\
\hline 4 & 0.058 & 0.351 & $\begin{array}{l}-0.019 * \\
(0.002)\end{array}$ \\
\hline 5 & 0.059 & 0.342 & $\begin{array}{l}-0.016 * \\
(0.002)\end{array}$ \\
\hline 6 & 0.059 & 0.329 & $\begin{array}{l}-0.020 * \\
(0.002)\end{array}$ \\
\hline 7 & 0.060 & 0.334 & $\begin{array}{l}-0.017 * \\
(0.002)\end{array}$ \\
\hline 8 & 0.069 & 0.320 & $\begin{array}{l}-0.018 * \\
(0.002)\end{array}$ \\
\hline 9 & 0.076 & 0.302 & $\begin{array}{l}-0.025 * \\
(0.003)\end{array}$ \\
\hline 10 & 0.090 & 0.273 & $\begin{array}{l}-0.022 * \\
(0.004)\end{array}$ \\
\hline
\end{tabular}

Notes: Standard errors are shown in parentheses. The superscript $*$ denotes statistical significance at the 1-percent level. Marginal effects are from probit regression models that include the explanatory variables shown in Table 6, as well as dummy variables that control for an individual's major industrial category. Unemployment figures used to determine decile rankings are from the U.S. Bureau of Labor Statistics, March 2009. 